\title{
Assessment of the Production, Technology and Marketing Challenges Facing Starch Producing Companies in Ghana
}

\author{
Ahlijah Bright, Samuel Yaw Akomea, Wilberforce Owusu-Ansah \\ School of Business, Kwame Nkrumah University of Science and Technology, Kumasi, Ghana \\ Email: brightahlijah@gmail.com
}

How to cite this paper: Bright, A., Akomea, S.Y. and Owusu-Ansah, W. (2017) Assessment of the Production, Technology and Marketing Challenges Facing Starch Producing Companies in Ghana. Open Journal of Business and Management, 5, 532542 .

https://doi.org/10.4236/ojbm.2017.53046

Received: February 9, 2017

Accepted: July 24, 2017

Published: July 27, 2017

Copyright $\odot 2017$ by authors and Scientific Research Publishing Inc. This work is licensed under the Creative Commons Attribution International License (CC BY 4.0).

http://creativecommons.org/licenses/by/4.0/

\begin{abstract}
Companies in the starch manufacturing sector in Ghana have over the years being bedeviled with major problems that cut across all their spheres of operation especially production, technology and marketing. The research sought to unearth the extent to which these three major problems affect the operations of these companies. A census was conducted of the management of Ayensu Starch Company where the two management members were selected and interviewed. The research established that there are production, technology and marketing challenges hindering the operations of ASCo. Management of the company has over the years taken stringent measures to reduce the impact of some of these problems to the barest minimum.
\end{abstract}

\section{Keywords}

Production Challenges, Technology Challenges, Marketing Challenges

\section{Introduction}

According to [1], constant changes in products, stoppage in constant communication and dissemination of information, developing new products, and improvement in technology, high staff replacement, conflicts between employees and management, and eminent business rivals form the major bedrock for uncertainties in a value chain. This outcome of these uncertainties is the distortion in the performance of the firm and its inability to satisfy customers. In that regard, aligning the internal operations to suit the activities of suppliers has stood up as the topmost decision taken by most organisations in the past decade among other alternatives [2] [3] and [4]. Manufacturers now have a closer working relationship with their customers so as to foster an improved business relation value chain [5] as a result sharing information between customers and 
manufacturers results in reduced costs and more effective business conduct [6]. Some specific productions, technological and marketing related challenges faced in value chains are discussed below.

\section{Literature Review}

For the purposes of this study, the researchers limited the literature on the challenges specifically to production, technology and marketing issues facing manufacturing firms.

\subsection{Production Challenges}

The principal concept underpinning maintainable production is to utilize limited resources in manufacturing goods and services and also reducing the level of environmental pollution. In addition, the works of [7] on lean principles championed the importance of consistently polishing all processes related to production in order to avoid wastage of resources. The resultant effects of these activities are not only limited to improvement in quality, reduction in waste and marginal increases in the share of the organisation's market but also giving the added advantage to the firm as being conscious of the immediate environment of its operations.

In this era of customer centeredness, it is very important for firms to customize goods and services and offer them to customers at mass production prices and also reduce the design-to-market contacts drastically through speed manufacturing especially for companies that adopt the methodology of the rounded system. In the assertion of [8], applying the principles of lean by management in its operations demands that key concepts and important practices of production exist and their economic feasibility and effectiveness will help probe the existence of newer markets. This is done by using methods related to innovation and productivity to reserve scarce resources, assume full control of the ratio of consuming product to available resource as well as extending the product's life span.

Turning off unwanted machines automatically in manufacturing processes can help reduce energy consumption [9] by the help of techniques which are optimized to perform multiple objectives which embodies the speed associated with the arrival of machine parts and the time it takes for the machines to warm up.

One way to take full advantage of utilization ratio of product in relation to resources is the production of an elastic and easily configured products that can serve varied uses in several applications. This concept that backs this occurrence is the "principle of modularity" which centres on the concept of bulk customization [10]. The tendency to take apart and get back together needed products is vital to ensure more adaptability in the product. Recycling is desirable as compared to remanufacturing as many parts of the inputs are mostly reused, though making use of consumed parts or products presents issues that bother on quality and dependability [11] and [12]. The reuse of products/parts faces some issues such as defining their life parts in terms of technology. Consequently, in indus- 
tries that experience a fast pace in technological developments, the off age parts are mostly outmoded therefore inhibiting their reuse in production. But for the component parts that can be reused, the properties of obtainability and dependability are vital properties that must be assessed. Obtainability shows the extent of how perfectly the component part is able to carry out its assigned functions and dependability examines the possibility of the component part working adequately during a given duration of time [12].

\subsection{Technology Challenges}

As companies start effecting viable activities, it is imperative to merge the system as one unit that is interconnected. The diverse methods that bothers on production such as achieving lean manufacturing, ensuring quality control and maintaining regulatory standards have to be entirely incorporated into a single workable system of management [12] that emphases on the whole value chain.

Recreation models produced by help of separate concepts in event simulation [13] help envisage the whole manufacturing system and examine possible environmental influences on the up-to-date system design bring about. This enables both systems designers and engineers to remake the system in order to increase its level of efficiency. In addition, information systems can be used efficiently to interruptedly observe key organisational issues such as usage of resources, generation of waste and by-product, levels of emission and production levels. A manufacturing system that is smart [14] makes use of information gathered to quickly respond to bring itself back on the path of sustainability.

\subsection{Marketing Challenges}

The increased quest for quality in the global marketplace has created stress on producers to keep greater schemes of marketing and set criteria for quality. [15] is of the view that practices in marketing are the best forecaster of measuring the performance of business as there exist a solid relation between the key marketing related practices and entire performance of a business. The entire marketing mix is amalgamation of the key variables which are product, price, place and promotion. Upon understanding the needs of their customers which help them to serve these customers better than that of competitors, organizations then develop their marketing mix programme. Designing appropriate marketing programmes, bringing together the resources and guiding of all activities and efforts are important areas that firms concern themselves with. The efficiency of the marketing department rest on how well the unit is organised and also the selection process of its personnel and how they are trained. This is because trends in the marketing practices have affected the running of companies [16]. Some conveyed concern that manufacturers have nothing to do with marketing, and others also resolve that have not been duly recognised, acknowledged, or even given the necessary resources by its own industry [17] consequently firms in a much more relaxed era have to comprehend the developing trends along several marketing areas though they continuously chart out policies that bother on marketing mix. 
It is worthy of note that firms are principally not doing well on the marketing front following the lack of suitable marketing approaches since in the globalisation era, these firms needed to contend with the activities of the medium, the large and the foreign companies as they face intense rivalry from these companies directly or indirectly which according to [18] are crucial causes of the botch that exist among smaller firms. With time, more and more clients are becoming influential because of accessible product ranges and powers of negotiating which have resulted in the generating rigid rivalry both in the home market and the markets abroad. Therefore, as a result of the amplified rivalry, it is important to choose suitable plans within the marketing mix that can aid in the accomplishment of organizational objectives and also assist them to continue to be operational and remain competitive in the markets.

\subsubsection{Product Mix}

The customer derives key value from the product purchased and consumed. Product generally is the item which is eventually swapped because customers need the product and the firm also wants cash from client in order to conduct business activities. Making a choice of which product to manufacture is grounded on the longstanding factor and on the lack of research geared towards marketing. With the commencement of the strategy in manufacturing, a further devotion is needed to aid in the way in which product quality, flexibility of processes, reliable delivery and costs of manufacturing influence the entire firm's business [19]. The client is enticed to the company due to the product or services offered by the company. Substandard quality and outmoded products no longer aid in persistence since the manufactured products differ in size and in units along their features and overall performance. The choice of procedures used in production must be made among the notable techniques which are closest to perfect ones, bearing in mind the path in which product is envisaged to tow into the future. It is therefore important for the small-scale industry to recognize the area where the first-rate competition is non-existent for them as compared to the larger industry in the market place [20]. A significant component of product strategy centres on the development of new product with new range of products and extended product line. Firms therefore need to change the out-of-date products with the novel product features such as design, wrapper, appearance, quality and brand. In modern times, the developing concerns in product managing which bothers on issues of technology, branding, brand building and growing trend in consumers' tastes and preferences, foreign products should be attached with the aid of reasonable and useful tools and related strategies. The exertions in building brands help the firm to relay the notable assurances to the customers throughout all spheres of the company's department, mediators and among key suppliers [21]. This is because in this modern era, consumers all over favour low priced goods that come with high quality levels [22].

\subsubsection{Price Mix}

The achievements in marketing activities depends to a large extent on the strate- 
gies of valuing which is used by the organisation since there is a positive link between the price charged on a product and its quality. Policies on pricing are geared towards increasing market share thus if the cost of the product is high, consumers will not purchase them but if the prices are moderate, the product is mostly likely to be sold quickly. Thus in the area of marketing management, pricing is one of the complications organisations must resolve. This is because pricing is the important part that produces proceeds in marketing while the remaining three Ps are ultimately linked to cost [23]. Companies therefore need to be extremely cautious about their decisions in pricing and should also ensure that their products are obtainable at extremely competitive prices after undertaking their analysis of the market thus instituting clear cut plans that link to giving out discounts and allowances which are mostly essential to meet the challenges in pricing.

\subsubsection{Promotion Mix}

Through the use of methods of promotion, target customers are made aware of the existence of products in addition to information about their features and embedded benefits. Modern day organizations cope with a multifaceted system of marketing communication. As products get positioned in the minds of consumers from time to time in a manner that is completely unpremeditated by producers, information provided and the image generated by advertising might possibly differ from characteristics of the product. The company in relaying information communicates with its intermediaries, patrons and the various publics. Thus, the overall promotional mix of the firm entails key tools such as publicizing, sales promotion, personal selling, public relations and others. In addition to these publicity methods, advertising through mobile phones is a seen as an innovative and customer centered approach to reach larger potential clients. It comprises of publicity in forms such as short message service (sms), messaging service, mobile alerts, and multimedia among others. Using mobile phone to advertise can save cost, easy to update target group and aid in instant response which in the end aids in the recall of brand and ensure interactivity among brands [24]. Usually, the organisation makes its initial contact with clients via its activities contained in the promotional strategies. Thus making use of the appropriate promotional devices and methods would benefit the organization to place its product in mind of the target market.

\subsubsection{Place Mix}

The place mix represents the identical agreement for the even flow of available goods and services from manufacturer to clients. The products is expected to be made obtainable by the clients at the exact period, in the accurate quantity and at the appropriate place or venue. Place there denotes organizational choices that concern the siting of outlets, transportation modes and level of adequate inventory to be kept. The utilization of intermediaries mostly goes down to their greater efficiency in making goods extensively obtainable and near to their targeted markets. Market mediators via their associates, knowledge, specialty and 
scope of operation, gives an organisation more than it can generally accomplish by itself. Thus firms have to agree on the use of diverse networks in transporting the products to consumers [25].

\section{Methodology}

This part offers a thorough overview of the methods employed in the study and how the data was collected and subsequently analysed. The research was descriptive in its approach and employed the use of a structured interview guide in assessing the views and concerns of the respondents interviewed. The researchers conducted a census and sought the views of the two (2) management members of ASCo, thus the Managing Director and the Accountant. The responses given by the respondents were analysed qualitatively using content analysis.

\section{Results and Discussion}

There are some constraints that affect ASCo in its quest to remain competitive and survive. These challenges have been categorised under three (3) main groups which are production, technology and marketing constraints and explained using a content analysis.

\subsection{Production Constraints}

One key production constraints that management faces is ineffective quality control mechanisms. To overcome this:

"Management has requested for retooling of the laboratory which has lost most of its equipment overtime through overuse and ageing."

To overcome the production challenge of ineffective quality control mechanism, management has requested for a retooling of the laboratory which has lost most of its equipment overtime through overuse and ageing. This request is yet to be honoured by government in order to enhance ASCo's laboratory work. This has also resulted in the inability of the company to develop new range of products as a way of extending its product line which can generate extra revenue since among others, it is noted that new product development is one of the sources of uncertainties in the value chain. This finding corresponds with that of [11] who view the value chain as a joint action to design systems that enhance development of quality control mechanisms as well as effective systems of delivery therefore it is imperative that all players in a value chain possess a primary objective of delivering to meet customers' needs.

Furthermore, in resolving the unreliable energy source to support production:

"Management has managed to procure and install a standby generator to power the production plant in the event of power outage from the national grid."

Also, unreliable energy source to ensure a smooth production process due to the intermittent supply of electricity has been a challenge to ASCo. This is be- 
cause management does not have a high capacity plant to power the production plant and machinery needed for continuous production in times of power outages. There is therefore a total halt in production when electricity supply become erratic causing the value chain players to lose revenue since the firm suspends the carting of cassava from the farmers and the customers are also unable to receive finished products to serve the end users.

\subsection{Technology Constraints}

Management is confronted with technological constraints. One of them is outmoded components and parts of the production plant. To this management stated that:

"Major parts of the plant are outmoded and needs to be replaced in order to ensure efficient and interrupted production."

Key among the technological challenges facing ASCo is the inability of the plant to undertake continuous production process of transforming the raw cassava into starch and pulp. This is due largely to the outmoded component parts of the plant which results in the frequent breakdown of the plant causing stoppage in the production process. To complicate issues, ASCo lacks the needed funds to procure these essential parts since revenue they accrue from the sale of starch and pulp is used to re-purchase raw cassava and also cater for other administrative expenses. Management therefore rely solely on government to make the funds available for such purchases which mostly take quite a long time for it to be approved due to the bureaucratic nature of the process.

Also, in explaining the lack of information systems that regulate production activities, management stated that:

"Currently ASCo does not have any information systems to monitor and regulate all production activities."

ASCo also lacks an effective information system which is important in monitoring the entire activities of the value chain thereby making the value chain management ineffective which is a threat to the survival of ASCo. This result corresponds with the study of [7] who emphasized the importance of applying information systems in manufacturing in order to analyse the existing design and improve upon the inefficient manufacturing system. Also, that of [14] underscored the importance of using information systems to continuously monitor the behaviour of a manufacturing firm in relation to utilising resources, controlling waste generation and emission level as well as production outputs.

\subsection{Marketing Constraints}

Also, some marketing challenges bothers on the four (4) marketing mixes that are blended to achieve the marketing activities of the firm. These four (4) marketing mixes are; price, product, promotion and place.

In explaining the constraints that are product related, management stated that: 
"ASCo is persistently unable to implement all quality control mechanisms in production."

In coming out with ASCo's outputs that can meet all quality standards and criteria, management of ASCo has designed effective quality control mechanisms but these mechanisms have not been effectively implemented due to the outmoded and over aged laboratory equipment and tools needed to conduct such experiments. These occurrences have over the years compromised the total quality management practices of ASCo especially in relation to starch production and have threatened its continued existence since according to [19] the production of inferior quality products do not help in the survival of manufacturing firms, thus an effective manufacturing strategy that aid in survival should pay requisite attention to the influence of quality of the product, degree of flexibility in the process, dependable delivery and the cost of manufacturing on the firm's core business.

Also, in pricing its products, management of ASCo stated:

"The price at which ASCo sells the finished products is lower than the cost of production but the selling price is not lower than what pertains in other places. It is just that our cost of production is affected by the inefficient plant. We are therefore working at improving the efficiency of the plant".

In pricing ASCo's products, management adopt pricing strategies which are intended to make the company competitive. This the company does by quoting prices of its finished products slightly higher that what competing firms in the same industry charge. The challenge here is although these prices are relatively high, they still fall below ASCo's cost of production therefore posing a threat to the survival of ASCo since the firm incurs losses from one production period therefore has no funds available for production activities for the next production period. This finding corresponds with that of [23] who sees pricing as a problem of any marketing management activity since it is the component that generates revenue hence companies should offer products at competitive prices by setting out policies that fall in line with findings from competitive market analyses.

In line with promotion challenges, management stated that:

"ASCo has a sinking brand image among potential and old customers due to its inability to serve all of its old and potential customers."

Since ASCo has established customers who readily purchase its finished products, management has not undertaken any form of promotional activity. This has resulted in the inability of ASCo to establish its brand in the minds of other potential customers who may patronise the company's product in the future. ASCo is therefore unable to establish a recall of its brand since no promotional activity (such as advertising, direct marketing, personal selling, public relations, exhibition, etc.) has been done to position the brand in the mind of potential customers. This finding correspond with that of [24] who suggested that cost effective and flexible promotional activities help to inform target groups in re- 
ceiving immediate feedback which eventually results in recall and interactivity of brands. Finally, in explaining the place related challenges, management stated that:

"ASCo lack vans to cart finished products from the company's premises to the final customers".

Management of ASCo in distributing its finished products communicates with customers who normally pick up the finished products from the company's premises. The company therefore does not make use of intermediaries to undertake the activity of making the finished products available to target markets. The company itself does not also have effective transportation systems that can cart the finished products to the premises of the customers, a situation that will attract some charges which will boast the revenue base of ASCo. The company therefore loses out on these minor sources of revenue which is needed to augment proceeds made from the sale of the finished products (starch and pulp). This result correspond with that of [14], who observed that the use of marketing intermediaries helps firms achieve more than the company operating on its own since the these intermediaries make available their unique trade secrets such as contacts, trading experiences, job specialization and scope of operation for use by the firm.

\section{Conclusion}

This research concentrated on analyzing the production, technology and marketing challenges facing starch producing companies in Ghana. It revealed the various problems; how it affected the companies and measures management has put in to get them resolved.

\section{References}

[1] Helo, P. (2005) Managing Agility and Productivity in the Electronics Industry. Industrial Management and Data Systems, 104, 567-777.

https://doi.org/10.1108/02635570410550232

[2] Rungtusanatham, M., Salvador, F., Forza, C. and Choi, T.Y. (2003) Supply-Chain Linkages and Operational Performance: A Resource-Based-View Perspective. International Journal of Operations \& Production Management, 23, 1084-1099. https://doi.org/10.1108/01443570310491783

[3] Sarkis, J., Talluri, S. and Gunasekaran, A. (2007) A Strategic Model for Agile Virtual Enterprises Partner Selection. International Journal of Operations \& Production Management, 27, 1213-1234. https://doi.org/10.1108/01443570710830601

[4] Wu, L. (2009) Supplier Selection under Uncertainty: A Switching Options Perspective. Journal of Industrial Management and Data Systems, 109, 191-205. https://doi.org/10.1108/02635570910930091

[5] Collin, J. and Lorenzin, D. (2006) Plan for Supply Chain Agility at Nokia: Lessons from the Mobile Infrastructure Industry. International Journal of Physical Distribution \& Logistics Management, 36, 418-430. https://doi.org/10.1108/09600030610677375

[6] Hoehn, W. (2003) Managing Organizational Performance: Linking the Balanced 
Scored to a Process Improvement Technique. Proceedings of the 4 th Annual International Symposium in Industrial Engineering on the Performance-Based Management, Kasetsart University, Bangkok, 1-12.

[7] Womack, J.P. and Jones, D.T. (1996) Lean Thinking: Banish Waste and Create Wealth in your Corporation. Simon and Schuster.

[8] Udah, E.B. (2010) Industrial Development, Electricity Crisis and Economic Performance in Nigeria. European Journal of Economics, Finance and Administrative Sciences, 18, 105-121.

[9] Mouzon, G., Yildirim, M.B. and Twomey, J. (2007) Operational Methods for Minimization of Energy Consumption of Manufacturing Equipment. International Journal of Production Research, 45, 4247-4271.

https://doi.org/10.1080/00207540701450013

[10] Pine, J.B. (1993) Mass Customization-The New Frontier in Business Competition. Harvard Business School Press, Boston.

[11] Anityasari, M., Bao, H. and Kaebernick, H. (2005) Evaluation of Product Reusability Based on a Technical and Economic Model: A Case Study of Televisions. Proceedings of IEEE International Symposium on Electronics and the Environment, New Orleans, 199-204. https://doi.org/10.1109/isee.2005.1437024

[12] Rusinko, C.A. (2008) Towards More Sustainable Management Systems: Through Life Cycle Management and Integration. Journal of Cleaner Production, 16, 1071 1080.

[13] Heilala, J., Vatanen, S., Tonteri, H., Montonen, J., Lind, S., Johansson, B. and Stahre, J. (2008) Simulation Based Sustainable Manufacturing System Design. In: Mason, S.J., Hill, R.R., Monch, L., Rose, O., Jefferson, T. and Fowler, J., Eds., Proceedings of the 2008 Winter Simulation Conference, 1922-1930. https://doi.org/10.1109/wsc.2008.4736284

[14] Nagel, M.H. and Tomiyama, T. (2004) Intelligent Sustainable Manufacturing Systems, Management of the Linkage between Sustainability and Intelligence, an Overview. IEEE International Conference on Systems, Man and Cybernetics, 4183-4188.

[15] Ellis, P.D. (2005) Market Orientation and Marketing Practice in a Developing Economy. European Journal of Marketing, 39, 629-645. https://doi.org/10.1108/03090560510590746

[16] Dutta, A.N. (1989) Strategic Market Planning: A System Approach. Indian Bicycle Channels, 5, 71-76.

[17] Sivanand, C.N. and Murthy, B.E.V.N. (1999) Marketing Orientation of Small-Scale Industries. Sedme, 26, 29-44.

[18] Chaston, I. (1997) Small Firm Performance Assessing the Interaction between Entrepreneurial Style and Organizational Structure. European Journal of Marketing, 31, 814-831.

[19] Meijboom, B. and Bart, V. (1997) International Manufacturing and Location Decisions. International Journal of Production Management, 17, 790-805.

[20] Sandesra, J.C. (1988) Small Scale Industrialisation: The Indian Experience. Economic and Political Weekly, March 26, 640-654. https://doi.org/10.1108/01443579710175565

[21] Ghodeswar, M.B. (2008) Building Brand Identity in Competitive Market: A Conceptual Model. Journal of Product and Brand Management, 17, 4-12.

[22] Nag, B. (2000) WTO Regime and Its Implications for Indian Small and Medium Enterprises Sector. Sedme, 27, 1-17. https://doi.org/10.1108/10610420810856468

[23] Shanker, U.P. and Vijendranath, G. (1997) Pricing Strategy as a Mean for Susten- 
ance and Growth. The Management Accountant, 32, 385-390.

[24] Labh, S. (2008) Mobile Advertising: Another Dimension in Promotion. ICFAI Advertising Express, March, 57-61.

[25] Nagayya, D. (2005) Enhancing Competitiveness among Small Enterprises. Sedme, $32,53-74$.

Submit or recommend next manuscript to SCIRP and we will provide best service for you:

Accepting pre-submission inquiries through Email, Facebook, LinkedIn, Twitter, etc. A wide selection of journals (inclusive of 9 subjects, more than 200 journals)

Providing 24-hour high-quality service

User-friendly online submission system

Fair and swift peer-review system

Efficient typesetting and proofreading procedure

Display of the result of downloads and visits, as well as the number of cited articles Maximum dissemination of your research work

Submit your manuscript at: http://papersubmission.scirp.org/

Or contact ojbm@scirp.org 